\title{
The Relationship Between Monocyte Level on Admission and in Hospital Mortality in ST-elevation Myocardial Infarction Patients
}

\section{ST-yükselmeli Miyokard İnfaktisü Hastalarında Başvuru Monosit Seviyesinin Hastane İçi Mortalite ile İlişkisi}

\author{
๑ Recep Hacl ${ }^{1}$, ๑ Muhammed Keskin², ๑ Şennur Ünal Dayı ${ }^{3}$ \\ ${ }^{1}$ Yalova State Hospital, Clinic of Cardiology, Yalova, Turkey \\ ${ }^{2}$ istanbul Sultan 2. Abdülhamid Han Sample Training and Research Hospital, Clinic of Cardiology, İstanbul, Turkey \\ ${ }^{3}$ istanbul Dr. Siyami Ersek Thoracic and Cardiovascular Surgery Training and Research Hospital, Clinic of Cardiology, Istanbul, Turkey
}

Background: Inflammation plays a key part in atherosclerotic processes. For inflammation balance, monocytes mission is essential. The importance of regulated inflammations has been known in ST-segment elevation patients for a long time. Therefore, we investigated the relationship between monocyte level on admission and in-hospital mortality in ST-elevation myocardial infarction (STEMI) patients.

Materials and Methods: A total of 2.341 serial patients in STEMI treated by primary percutaneous coronary intervention in a tertiary heart center between December-2008 and October-2014 were enrolled and categorized into two groups as low and high monocyte groups.

Results: There were 1.594 (68.0\%) patients in the low monocyte $\left(\leqslant 0.7 \times 10^{\wedge} 3 / \mu \mathrm{L}\right)$ group and $747(31.9 \%)$ patients in the high monocyte $\left(>0.7 \times 10^{\wedge} 3 / \mu \mathrm{L}\right)$ group. High monocyte group had larger size infarct area so impaired left ventricular ejection fraction. In multivariate analysis, monocyte count remained as an independent factor for in-hospital deaths (odds ratio: $2.63,95 \%$ confidence interval: $1.07-6.47 ; p=0.040)$.

Conclusion: The current study demonstrated that admission monocyte level was independently related to in-hospital death. Therefore, admission monocyte count might be a useful tool in early risk scoring for STEMI patients.

Keywords: Primary PCI, ST-segment elevation myocardial infarction, monocyte level

Amaç: Enflamasyon, aterosklerozun patogenezinde anahtar rol oynar ve monositler enflamasyonun ana düzenleyicilerinden biridir. ST yükselmeli miyokard enfarktüsü (STyME) hastalarında iyi dengelenmiş enflamasyonun önemi uzun yıllardır tanımlanmıştır. Bunun sonucu olarak, STyME ile hastaneye başvuran hastaların başvuru monosit değeri ile hastane içi ölüm arasındaki ilişkiyi araştırdık.

Gereç ve Yöntemler: Aralık 2008-Ekim 2014 tarihleri arasında üçüncü basamak bir kalp merkezine başvuran ve primer perkütan girişim uygulanmış 2,341 STyME hastası kayıt altına alınıp yüksek ve düşük monosit sayısına göre iki gruba ayrıldı.

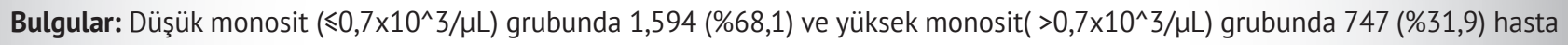
bulunmaktaydı. Yüksek monosit grubunda daha fazla infarkt alanı ve dolayısıyla daha düşük ejeksiyon fraksiyonu tespit edildi. Yapılan çoklu değişkenli analizde monosit değeri ile hastane içi ölüm arasında bağımsız ilişki bulundu (odds oranı: 2,63, \%95 güven aralığı: 1,07-6,47; p=0,040).

Sonuç: Bu çalışmada başvuru monosit değeri ile hastane içi ölüm arasında bağımsız ilişki gösterildi. Sonuç olarak başvuru monosit değeri, STyME hastalarının erken risk skorlamasında kullanışlı olabilir.

Anahtar Kelimeler: Primer PKG, ST-yükselmeli miyokard infarktüsü, monosit sayısı 


\section{Introduction}

ST-segment elevation myocardial infarction (STEMI) is the most important type of acute coronary syndromes (1). Inflammation and immunological processes play an important role particularly in the development and pathogenesis of acute coronary syndromes: STEMI, nonSTEMI, and unstable angina pectoris (2). Immune system cells like lymphocytes, neutrophils and monocytes are significantly associated with atherosclerotic processes, endothelial dysfunction, and ventricular remodeling in patients with STEMI. Monocytes are a part of innate immunity and are involved in reparative processes. Recent studies revealed that plateletcrit (3) ratio of neutrophil-tolymphocyte (NLR) $(4,5)$, ratio of lymphocyte-to-monocyte $(6,7)$ and ratio of eosinophil-to-monocyte (EMR) (8) were directly related to severity, mortality and clinical outcomes in STEMI and coronary artery diseases. Here, our purpose was to determine the relationship between the monocyte level on admission and in-hospital mortality in STEMI patients.

\section{Materials and Methods}

\section{Study Population}

We enrolled a total of 2.341 consecutive patients with STEMI, who were treated with primary percutaneous coronary intervention (PPCl) and whose chest pain duration was lower than 24 hours, from December, 2008 to October, 2014 in a tertiary heart center. STEMI was described to be typical angina pectoris longer than 20 minutes, with new onset of left bundle branch block or ST elevation $>1 \mathrm{~mm}$ at minimum two contiguous leads on the electrocardiogram and $>2$ fold up in serum cardiac markers, specifically troponin (9). Patients having cardiogenic shock and active infections and being treated with thrombolytic therapy were excluded. We divided all patients into two groups. The first group was named as the low monocyte group, which meant monocyte count was equal or lower than $0.7 \times 10^{\wedge} 3 / \mathrm{uL}$, and the other group was named as the high monocyte group, which meant monocyte count was higher than $0.7 \times 10^{\wedge} 3$ / uL. Ethics committee approval and patient consent were obtained for the study.

\section{Coronary Angiography}

All patients received antiaggregant therapy with clopidogrel $(600 \mathrm{mg})$ and aspirin $(300 \mathrm{mg})$ prior to $\mathrm{PPCl}$. Also, during the procedure, patients were treated with intravenous bolus of unfractionated heparin at a dose of $70-100 \mathrm{U} / \mathrm{kg}$ of body weight. The statin, beta-blocker agents which had no contraindications were ordered for the patients. Stenting was the main interventional treatment in our center. Radial or femoral approach, using of balloon for predilatation or postdilatation, stent type, and all equipment were left to the operator's decision.

\section{Data Collection}

All patients' age, gender, current smoking status, comorbidities such as hypertension, diabetes, hyperlipidemia, and chronic renal failure were recorded. Also, past medical histories including myocardial infarction, $\mathrm{PCl}$, or coronary artery bypass graft stories of patients were recorded. Blood samples were taken prior to aspirin and clopidogrel administration for the measurement of laboratory parameters. Blood samples were taken into standard Ethylenediaminetetraacetic acid containing tubes and evaluated by an automated blood cell counter (LH 780; Beckman co.). All biochemical parameters were noted. Echocardiographic assessment was performed before PPCI with GE ViVidE7 ultrasound machine by using the Simpson's method. Left ventricular ejection fraction was measured in apical four chamber view. We also recorded the patients' angiographic characteristics.

\section{Statistical Analysis}

All continuous variables were expressed as mean \pm standard deviation. The Kolmogorov-Smirnov test was used for testing normality. The independent sample t-test was used for continuous variables displaying normal distributions. The Mann-Whitney $U$ test was performed for continuous variables with skewed distributions. Categorical variables were expressed as number and percentages and the Pearson's chi-square test was employed for the evaluation of differences. For multivariable analysis, hierarchical logistic regression model was used. The odds ratio (OR) demonstrated the relative risk of death in the groups. Confounders of multivariate analysis were the predictors of in-hospital mortality. The $p$-value of $<0.05$ was considered statistically significant, and $95 \%$ confidence intervals $(\mathrm{Cl})$ were presented for all hazard and ORs. Statistical Package for Social Sciences software, version 15.0 (SPSS; IBM, Armonk, New York, USA) was used for analyses.

\section{Results}

A total of 2.341 patients were included in our study and treated with $\mathrm{PPCl}$, and stent implantation was technically successful. The patients were classified into two groups: low monocyte and high monocyte groups, as shown in Table 1. The mean age of patients was 57 years, and 1.989 
Table 1. Baseline and laboratory characteristics of patients

\begin{tabular}{|c|c|c|c|}
\hline Variables & $\begin{array}{l}\text { Low monocyte }\left(\leqslant 0.7 \times 10^{\wedge} 3 / \mu L\right) \\
(n=1.594)\end{array}$ & $\begin{array}{l}\text { High monocyte }\left(>0.7 \times 10^{\wedge} 3 / \mu L\right) \\
(n=747)\end{array}$ & p \\
\hline Age, y & $57.82 \pm 11.6$ & $55.44 \pm 11.87$ & $<0.001$ \\
\hline Male, $\mathrm{n}$ & $1323(56.5 \%)$ & $666(28.4 \%)$ & $<0.001$ \\
\hline Diabetes, n & $410(17.5 \%)$ & 183 (7.8\%) & 0.542 \\
\hline Hypertension, $\mathrm{n}$ & 477 (20.3\%) & 201 (8.5\%) & 0.146 \\
\hline Current smoking, $\mathrm{n}$ & 607 (25.9\%) & $343(14.65 \%)$ & $<0.001$ \\
\hline Hyperlipidemia, n & 434 (18.53\%) & 196 (8.3\%) & 0.638 \\
\hline Stroke, n & 24 (1.0\%) & $8(0.3 \%)$ & 0.413 \\
\hline Previous CABG, $n$ & $40(1.7 \%)$ & $28(1.1 \%)$ & 0.095 \\
\hline Previous $\mathrm{PCl}, \mathrm{n}$ & 207 (8.8\%) & 94 (4.0\%) & 0.874 \\
\hline In-hospital mortality, n & $30(1.2 \%)$ & $24(1.0 \%)$ & 0.046 \\
\hline Hemoglobin, g/L & $13.5 \pm 1.7$ & $13.9 \pm 1.9$ & $<0.001$ \\
\hline White blood cell count, $10^{9} / \mathrm{L}$ & $11.1 \pm 4.0$ & $14.5 \pm 4.6$ & $<0.001$ \\
\hline Platelet count, $10^{9} / \mathrm{L}$ & $233 \pm 67$ & $249 \pm 70$ & $<0.001$ \\
\hline Monocyte count, $10^{9} / \mathrm{L}$ & $0.48 \pm 0.1$ & $1.02 \pm 0.6$ & $<0.001$ \\
\hline Serum creatinine, $\mathrm{mg} / \mathrm{dL}$ & $0.91 \pm 0.3$ & $0.94 \pm 0.3$ & 0.014 \\
\hline Total cholesterol, mmol/L & $184 \pm 51$ & $178 \pm 45$ & 0.018 \\
\hline Triglyceride, $\mathrm{mmol} / \mathrm{L}$ & $156 \pm 102$ & $163 \pm 103$ & 0.141 \\
\hline $\mathrm{HDL}, \mathrm{mmol} / \mathrm{L}$ & $38.2 \pm 10.2$ & $36.8 \pm 10.2$ & 0.004 \\
\hline $\mathrm{LDL}, \mathrm{mmol} / \mathrm{L}$ & $114.6 \pm 39.1$ & $109.0 \pm 36.6$ & 0.003 \\
\hline Glucose, mg/dL & $159.2 \pm 80.1$ & $157.9 \pm 82.0$ & 0.712 \\
\hline CKMB, U/L & $156 \pm 144$ & $177 \pm 171$ & 0.004 \\
\hline Troponin, ng/mL & $49.0 \pm 4.5$ & $49.1 \pm 5.7$ & 0.915 \\
\hline
\end{tabular}

\section{Table 2. Angiographic characteristics of patients}

Variables

Infarct-related coronary artery

LAD

LCX

RCA

Number of used stents

Contrast agent use, $\mathrm{mL}$

Multivessel disease

Tirofiban use

\begin{tabular}{|l|l|l|}
\hline $\begin{array}{l}\text { Low monocyte }\left(\leqslant 0.7 \times 10^{\wedge} 3 / \mu \mathrm{L}\right) \\
(\mathrm{n}=1594)\end{array}$ & $\begin{array}{l}\text { High monocyte }\left(>0.7 \times 10^{\wedge} 3 / \mu \mathrm{L}\right) \\
(\mathbf{n = 7 4 7 )}\end{array}$ & $\mathbf{p}$ \\
\hline $\begin{array}{l}681(29.0 \%) \\
230(9.8 \%) \\
649(27.7 \%)\end{array}$ & $\begin{array}{l}339(14.4 \%) \\
127(5.4 \%) \\
261(11.1 \%)\end{array}$ & 0.031 \\
\hline $1345(57.4 \%)$ & $607(25.4 \%)$ & 0.074 \\
\hline $244 \pm 85$ & $250 \pm 87$ & 0.132 \\
\hline $301(12.8 \%)$ & $157(6.7 \%)$ & 0.214 \\
\hline $759(32.4 \%)$ & $387(16.5 \%)$ & 0.051 \\
\hline
\end{tabular}

LAD: Left anterior descending artery, LCx: Left circumflex artery, RCA: Right coronary artery

patients were male, 352 patients were female. We listed the demographic, laboratory and clinical characteristics in Table 1. We also analyzed angiographic characteristics and demonstrated them in Table 2. We searched the variables' effects on in-hospital mortality and reached the result that high monocyte count, high LDL level, old age (>65 age), male gender, diabetes, high serum creatine level (>2 gr/dL), low left ventricular EF (<\%50) and high CK-MB directly were associated with in-hospital death (Table 3). Multivariate analysis determined that the independent parameters of inhospital mortality, high monocyte count (OR: $2.63 ; 95 \% \mathrm{Cl}$ : 1.07-6.47; $p=0.03$ ), older age, diabetes, high LDL level, low left ventricular EF and high CK-MB level were independently related to in-hospital mortality (Table 4). 


\begin{tabular}{|l|l|l|l|}
\hline Table 3. Univariate analysis & $\begin{array}{l}\text { Odds } \\
\text { Variables }\end{array}$ & $\begin{array}{l}95 \% \\
\text { confidence } \\
\text { interval }\end{array}$ & p \\
\hline Male & 0.45 & $0.24-0.83$ & 0.013 \\
\hline Age & 1.07 & $1.05-1.10$ & $<0.001$ \\
\hline Creatinine & 9.20 & $5.52-15.34$ & $<0.001$ \\
\hline Diabetes & 3.82 & $2.21-6.59$ & $<0.001$ \\
\hline Hypertension & 1.70 & $0.98-2.96$ & 0.051 \\
\hline Current smoking & 0.66 & $0.37-1.19$ & 0.174 \\
\hline Hyperlipidemia & 0.21 & $0.07-0.59$ & 0.003 \\
\hline Chronic renal failure & 9.33 & $3.95-22.04$ & $<0.001$ \\
\hline Peak CKMB & 1.00 & $1.00-1.00$ & $<0.001$ \\
\hline Previous PCI & 0.84 & $0.35-1.98$ & 0.696 \\
\hline LVEF & 0.91 & $0.89-0.93$ & $<0.001$ \\
\hline White blood cell count & 1.11 & $1.06-1.16$ & $<0.001$ \\
\hline Hemoglobin count & 0.83 & $0.72-0.96$ & 0.012 \\
\hline Platelet count & 1.00 & $0.99-1.00$ & 0.926 \\
\hline HDL & 0.95 & $0.91-1.00$ & 0.053 \\
\hline LDL & 0.96 & $0.95-0.98$ & $<0.001$ \\
\hline Peak troponin & 0.98 & $0.94-1.03$ & 0.513 \\
\hline High monocyte & 1.73 & $1.00-2.98$ & 0.041 \\
\hline $\begin{array}{l}\text { CKMB: Creatine kinase-myocardial } \\
\text { LDL: Land, HDL }: \text { High density }\end{array}$ & lipoprotein, \\
\hline Percutaneous coronary interventio & Left ventricular ejection fraction, PCI: \\
\hline
\end{tabular}

\section{Table 4. Multivariate analysis}

\begin{tabular}{|l|l|l|l|}
\hline Variables & Odds ratio & $\begin{array}{l}\text { 95\% confidence } \\
\text { interval }\end{array}$ & $\mathbf{P}$ \\
\hline Age & 1.07 & $1.03-1.11$ & $<0.001$ \\
\hline Diabetes & 2.54 & $1.04-6.18$ & 0.042 \\
\hline LVEF & 0.95 & $0.91-1.04$ & 0.051 \\
\hline LDL & 0.97 & $0.95-0.98$ & $<0.001$ \\
\hline Peak CKMB & 1.00 & $1.00-1.00$ & $<0.001$ \\
\hline High monocyte & 2.63 & $1.07-6.47$ & 0.031 \\
\hline
\end{tabular}

CKMB: Creatine kinase-myocardial band, LDL: Low density lipoprotein, LVEF: Left venricular ejection fraction

\section{Discussion}

Monocytes have an important role in atherogenesis and take part in inflammation (10). Monocytes consist of heterogeneous cell population and contain several surface expressions like CD14 and CD16 (11). CD16+ monocytes entitled proinflammatory cells and answer on inflammation (12). Also, monocytes have been effective in lots of systemic inflammatory diseases like rheumatoid arthritis and systemic lupus erythematosus. In atherosclerotic way, monocytes are related to stable and unstable plaque (13). In more than 900 stable CAD patients, it was shown that high monocyte count was strongly related to adverse cardiovascular events. (14).

Monocytes are modifiable cells enhancing their interaction with endothelial cells and myocardial cells. Increased expression of MAC-1 receptor leads to robust monocyte adhesion to the endothelial tissue (15). Intercellular adhesion molecule-1 (ICAM-1), vascular cell adhesion molecule-1 (VCAM-1), and L-selectin levels also increase in beginning part of acute coronary syndromes (16). Acute coronary syndromes are related to upregulation of some receptors like fibronectin receptor VLA-5, the mission of which is migration to tissue and very important part of cardiac extracellular matrix proteins (17). In acute coronary syndrome pathogenesis, monocyte chemoattractant protein (MCP-1) and macrophage colony stimulating factor (M-CSF) play a role in monocyte collection into the infarct zone, differentiation of monocytes to macrophages in the infarct area (18). MCP-1 (gene name CCL2, receptor gene name CCR2) is the most important chemokine that orchestrates to the macrophages' roles. Blood flow reduction stimulates MCPpositive macrophage infiltration of injured myocardium. (19). Circulating monocytes produce high plasma levels of MCP-1 in acute coronary syndromes, and this situation leads to neovascularization, so much macrophage collection and accumulation of myofibroblasts that affects left ventricular remodeling (20).

Our study showed an important relationship between high blood level of monocytes and in-hospital mortality in STEMI patients who were treated with $\mathrm{PPCI}$. In previous studies, researchers have collected lots of information to show an association between inflammatory cells and development processes of atherogenesis. For remembering, monocytes play a key role in atherosclerosis firstly (21). Endothelial dysfunction leads to the accumulation of inflammatory cells in the endothelium of arterial wall (22). Monocytes which migrate to the tissue get the name of macrophage (23). Macrophages release some factors like interleukin-6 (IL-6), tumor necrosis factor alpha for more inflammation (24). Lots of clinical studies have shown that advanced monocyte level is associated with high inflammation, large infarct areas, and left ventricular dysfunction (25). Inhibiting monocytes collecting to infarcted myocardium tissue might prevent loss of left ventricular ejection fraction (26). Some studies focused on eosinophil to monocyte ratio (27) and neutrophil to lymphocyte ratio (28), and they showed again inflammation strongly related to pathogenesis of atherosclerosis.

In present study, we clearly showed that high monocyte level in patients with STEMI was related to larger infarct size, lower left ventricular ejection fraction and higher in- 
hospital mortality. Therefore, monocyte level on admission may be useful for the prediction of early risk score for inhospital mortality.

\section{Study Limitations}

Our study has several limitations. First, it was a single center and retrospective study. Second, we excluded STEMI patients having cardiogenic shock on admission, active infection and being treated with thrombolytic therapy. We need larger patient population and prospective and randomized clinical studies for suggestion of our findings.

\section{Conclusion}

We showed that higher monocyte level on admission was related to higher risk for in-hospital mortality. Monocyte count could be a simple and useful biomarker for risk stratification in STEMI patients.

\section{Ethics}

Ethics Committee Approval: Ethics committee approval and patient consent were obtained for the study (protocol number: 28001928-501.07.0l-29.07.15).

Informed Consent: Patient consent were obtained for the study.

Peer-review: Externally and internally peer-reviewed.

\section{Authorship Contributions}

Surgical and Medical Practices: R.H., Concept: R.H., Design: M.K., Data Collection or Processing: R.H., Analysis or Interpretation: M.K., Literature Search: Ş.Ü.D., Writing: R.H.

Conflict of Interest: No conflict of interest was declared by the authors.

Financial Disclosure: The authors declared that this study received no financial support.

\section{References}

1. Reed G, Rossi JE, Cannon CP. Acute myocardial infarction. Lancet. 2017;389:197-210. [Crossref]

2. Liu HL, Yang Y, Yang SL, Luo JP, Li H, Jing LM, et al. Administration of a loading dose of atorvastatin before percutaneous coronary intervention prevents inflammation and reduces myocardial injury in STEMI patients: a randomized clinical study. Clin Ther. 2013;35:261-272. [Crossref]

3. Keskin M, Kaya A, İpek G, Bolca O, Doğan S, Özçelik F, et al. A simple Independent predictor of in-hospital and long-term outcomes in patients with STEMI: Plateletcrit. Hamidiye Med J. 2020;1:22-28. [Crossref]

4. Ayça B, Akın F, Çelik Ö, Şahin I, Yıldız SS, Acvı Ii, et al. Neutrophil to lymphocyte ratio is related to stent thrombosis and high mortality in patients with acute myocardial infarction. Angiology. 2015;66:545-552. [Crossref]

5. Keskin Ü, Günay N, Kayataş K. Neutrophil-to-lymphocyte ratio for the assessment of long-term mortality in patients with heartf failure. Hamidiye Med J. 2020;1:29-35. [Crossref]
6. Wang O, Ma J, Jiang Z, Wu F, Ping J, Ming L. Association of lymphocyteto-monocyte ratio with in-hospital and long-term major adverse cardiac and cerebrovascular events in patients with ST-elevated myocardial infarction. Medicine (Baltimore). 2017;96:e7897. doi: 10.1097/ MD.0000000000007897.

7. Murat SN, Mikail Yarlıoğlues M, Çelik IE, Kurtul A, Duran M, Kılıç A, et al. The relationship between lymphocyte-to-monocyte ratio and bare- metal stent in-stent restenosis in patients with stable coronary artery disease. clin appl thromb hemost. 2017;23:235-240. [Crossref]

8. Xin D, Wang X, Shen L, Yao K, Ge L, Ma J, et al. Assosciation of eosinophil to monocyte ratio with 1 month and long term all cause mortality in patients with STEMI undergoing primary PCI. J Thorac Dis. 2018;10:5449-5458. [Crossref]

9. Thygesen K, Alpert JS, Jaffe AS, Simoons ML, Chaitman BR, White HD, et al. Third universal definition of myocardial infarction. Eur Heart J. 2012;33:2551-2567. [Crossref]

10. Krychtiuk KA, Kastl SP, Speidl WS, Wojta J. Inflammation and coagulation in atherosclerosis. Hamostaseologie. 2013;33:269-282. [Crossref]

11. Passlick B, Flieger D, Ziegler-Heitbrock HW. Identification and Characterization of a novel monocyte subpopulation in human peripheral blood. Blood. 1989;74:2527-2534. [Crossref]

12. Ziegler-Heitbrock L. The CD141 CD161 blood monocytes: their role in infection and inflammation.J Leukoc Biol. 2007;81:584-592. [Crossref]

13. Imanishi T, Ikejima H, Tsujioka H, Kuroi A, Ishibashi K, Komukai K, et al. Association of monocyte subset counts with coronary fibrous cap thickness in patients with unstable angina pectoris. Atherosclerosis. 2010;212:628635. [Crossref]

14. Rogacev KS, Cremers B, Zawada AM, Seiler S, Binder N, Ege P, et al. CD1411CD161 monocytes independently predict cardiovascular events: a cohort study of 951 patients referred for elective coronary angiography. J Am Coll Cardiol. 2012;60:1512-1520. [Crossref]

15. Kashiwagi M, Imanishi T, Tsujioka H, Ikejima H, Kuroi A, Ozaki Y, et al. Association of monocyte subsets with vulnerability characteristics of coronary plaques as assessed by 64-slice multidetector computed tomography in patients with stable angina pectoris. Atherosclerosis. 2010;212:171-176. [Crossref]

16. Poitou C, Dalmas E, Renovato M, Benhamo V, Hajduch F, Abdennour M, et al. CD14dimCD16+ and CD14+CD16+ monocytes in obesity and during weight loss: relationships with fat mass and subclinical atherosclerosis. Arterioscler Thromb Vasc Biol. 2011;31:2322-2330. [Crossref]

17. Rothe G, Gabriel H, Kovacs E, Klucken J, Stöhr J, Kindermann W, et al. Peripheral blood mononuclear phagocyte subpopulations as cellular markers in hypercholesterolemia. Arterioscler Thromb Vasc Biol. 1996;16:1437-1447. [Crossref]

18. Rothe G, Herr AS, Stöhr J, Abletshauser C, Weidinger G, Schmitz G. A more mature phenotype of blood mononuclear phagocytes is induced by fluvastatin treatment in hypercholesterolemic patients with coronary heart disease. Atherosclerosis. 1999;144:251-261. [Crossref]

19. Kakio T, Matsumori A, Ono K, Ito H, Matsushima K, Sasayama S. Roles and relationship of macrophages and monocyte chemotactic and activating factor/monocyte chemoattractant protein-1 in the ischemic and reperfused rat heart. Lab Invest. 2000;80:1127-1136. [Crossref]

20. Morimoto H, Takahashi M, Izawa A, Ise H, Hongo M, Kolattukudy PE, et al. Cardiac overexpression of monocyte chemoattractant protein-1 in transgenic mice prevents cardiac dysfunction and remodeling after myocardial infarction. Circ Res. 2006;99:891-899. [Crossref]

21. Moreno P, Falk E, Palacios IF, Newell JB, Fuster V, Fallon JT. Macrophage infiltration in the acute coronary syndrome. Implication for plaque rupture. Circulation. 1994;90:775-778. [Crossref]

22. Gerszten R, Friedrich EB, Matsui T, Hung RR, Li L, Force T, et al. Role of phosphoinositide 3-kinase in monocyte recruitment under flow conditions. J Biol Chem. 2001;276:26846-26851. [Crossref]

23. Falk E, Shah PK, Fuster V. Coronary plaque distruption. Circulation. 1995;92:665-671. [Crossref] 
24. Jugdutt B. Monocytes and adverse left ventricular remodeling after reperfused myocardial infarction. J Am Coll Cardiol. 2002;39:247-250. [Crossref]

25. Singh U, Devaraj S, Jialal I. Vitamin E, oxidative stress, and inflammation. Annu Rev Nutr. 2005;25:151-174. [Crossref]

26. Clemente C, Rius C,Alonso-Herranz L, Martin-Alonso M,Pollan A, Camafetia $\mathrm{E}$, et al. MT4-MMP deficiency increases patrolling monocyte recruitment to early lesions and accelerates atherosclerosis. Nat Commun. 2018;9:910. [Crossref]
27. Gijsberts C, Ellenbroek GHJM, Berg MJT, Huisman A, van Solinge WW, Lam CS, et al. Effect of monocyte-to-lymphocyte ratio on heart failure characteristics and hospitalizations in a coronary angiography cohort. Am J Cardiol. 2017;120:911-916. [Crossref]

28. İyisoy A, Balta S, Celik T, Mikhailidis DP, Ozturk C, Demirkol S, et al. The relation between atherosclerosis and the neutrophil-lymphocyte ratio. Clin Appl Tromb Hemost. 2016;22:405-411. [Crossref] 